\title{
Plain Language in Law in Hungary
}

\author{
Edina VINNAI \\ Department of Jurisprudence and Sociology of Law \\ University of Miskolc, Hungary \\ edinavinnai@gmail.com
}

\begin{abstract}
Plain language movement has a long history and has achieved significant changes in the USA and in many European countries. However, the situation is not as good as that in Hungary, especially in the field of law. As a researcher in two empirical "law and language" projects in Hungary since 2000, the author presents her experiences gained during preparing and analysing tape recordings of police interrogations and court hearings as regards comprehension of legal language. The paper focuses especially on the understandability of providing information on the rights and obligations of laymen in legal procedures given by legal professionals. It also summarizes the recent changes in Hungarian legal regulations providing a better understanding of rights and obligations (partly based on the 2012/13/ EU Directive on the right to information in criminal proceedings). As regards the practice of adjudication, the paper compares the way of providing information to laymen before and after the modification of legal norms. Two positive examples can be mentioned: (1) a few years ago, a group of legal and linguistic experts prepared a so-called Stylebook with recommendations to improve the structure and wordings of court verdicts, and (2) within the framework of a project called The Year of Comprehensibility at Courts, 2017 the improvement of comprehensible communication was integrated into an obligatory training for judges.
\end{abstract}

Keywords: plain legal language, intralingual translation, linguistic model of adjudication, right to information in criminal proceedings, right to fair trial

\section{The plain language movement}

The Plain Language (or in English-speaking countries: Plain English) Movement is a discipline with the aim of making official or any type of technical language more comprehensible. It includes many plainers, practitioners, and campaigners worldwide, and several organizations were established in this field over the last 40 years. In 2007, the two main international umbrella organizations, Clarity (formed by a British local government solicitor in 1983 for lawyers) and PLAIN 
(Plain Language Association International, a Canada-based but international nonprofit company), and the Center for Plain Language in the USA decided to work jointly on developing plain language as a profession and formed the International Plain Language Federation ${ }^{1}$ at the 2007 PLAIN conference in Amsterdam.

However, there is no generally accepted definition of plain language. So, we can find several, more or less identical concepts. On the IPL Federation website, plain language is defined in several languages (in English, Spanish, Swedish, Dutch, Hungarian, Norwegian, Chinese, German, Portuguese, French, Finnish, Italian, Greek, Indonesian, Romanian, Russian, Catalan, and Japanese); the English definition is the following: "A communication is in plain language if its wording, structure, and design are so clear that the intended readers can easily find what they need, understand what they find, and use that information." Result-based definitions imply that plain language is not a dialect of the standard language but a relationship between the text and its audience. Therefore, a text that will be plain for one audience will not be plain for another (Adler 2012: 68).

Within the EU, the European Commission also pays attention to clear writing, and in 2011 hand-outs were prepared in all official languages in order to provide some hints on how to write clearly. ${ }^{2}$ Three reasons are mentioned why a clear document should be more effective and more easily and quickly understood: (i) to work more effectively together, (ii) to reduce unnecessary correspondence, and (iii) to build goodwill.

As we can see from the above definitions, law is only one aspect of the movement besides, for example, plain medicine, plain government, plain technical writing, plain finance, and plain scientific papers. Some legal plainers are practising lawyers who write plainly for their clients: they might be private lawyers offering intelligible documents to the public, government lawyers drafting plain legislation, or they help lawyers redraft their standard documents and train them to write plainly for themselves; some are academics teaching the next generation of lawyers to communicate plainly (Adler 2012: 70).

If we compare advantages and disadvantages of plain legal language and of legalese (the traditional style of legal writing), the following issues arise. According to plainers, plain language is more precise, and fewer errors may occur simply because of fewer words and expressions. Plain drafting of legal texts makes it quicker and cheaper to obey the law because people can skip high attorney fees for explaining legal jargon. A plain legal text can be more persuasive for laymen, more democratic because it promotes better access to justice, and, finally, more elegant (however, this is obviously not the most important aspect of legal texts). Proponents of plain legal language list the following requirements, the $4 \mathrm{C}$-s:

1 http://www.iplfederation.org/

2 https://publications.europa.eu/en/publication-detail/-/publication/c2dab20c-0414-408d-87b5dd3c6e5dd9a5 
legal texts need to be Clear, Correct, Concise, and Complete. On the other hand, proponents of legalese claim that complex ideas, such as those formulated in legal texts, require complex language, and plain language represents irresponsible over-simplification, wherefore plain language is not always appropriate in legal documents (Adler 2012: 71-73).

Probably, we could continue the pros and cons for and against plain language and legalese, but what is sure is that laws are written to be followed and the very fact and everyday experiences that there are doubts and difficulties about interpretation and understanding of legal texts show that something has gone wrong, and something has to be done. A further consideration is that all legal systems have the general presumption that everyone is presumed to know the law, and ignorance of the law is no excuse. From this presumption, one can conclude that law has to be available and accessible to all, and the state also has the interest to enact effective laws and other legal documents (e.g. court judgments) so that people can easily obey them.

There are further arguments (Tiersma 1999: 69) supporting that the reform of legal language may be necessary to protect lawyers from public criticism and rejection as well since one perception is that legalese is unnecessarily exclusive and that preserving stylistic features, such as lengthy and complex sentences with a high degree of subordination and embedding, wordiness, conjoined phrases, impersonal constructions, etc., "excludes those who do not belong". (This is what we called in our research projects an element of the right to fair trial and access to justice.) However, counter-arguments (Bhatia 2010: 46) say that in legislative writing processes of simplification (carried out under a reformist project) can lead to under-specification, and this has implications for power and control: if the legislature goes for simplicity, it paradoxically gives power to the judiciary to interpret the law and take it away from the people whom the legislature represents.

The obstacles of understanding legal texts stem from several reasons, and these reasons can be found at almost all levels of language such as grammar, syntax, semantics, and vocabulary. The length of a sentence is crucial when assessing the level of complexity in a text. For example, as regards the syntactic structure of British legislative language, researchers found that from 1975 by 2001 sentences became shorter, and their complexity decreased. They also found that there are fewer subordinate clauses in sentence-medial positions, which is the most difficult to understand for non-lawyers, while right-branching syntax is more preferred. Furthermore, one can experience layout devices that make it easier to comprehend legislative texts, while the length of a sentence may increase. Using passive voice instead of active or nominalized verb forms are typical reasons for obscurity as well (Gustafsson 1975, Hiltunen 2001).

As regards vocabulary, researchers found - and laypersons can experience the same too - that in legal texts there are more nouns than verbs or adjectives. 
The reason for that, according to linguists, is that there is a belief that nouns create an impression of greater objectivity than verbs. Compound words and phrases, archaic words and phrases, words of foreign (mainly Latin) origin, legal abbreviations and acronyms, polysemy (the same term may express several concepts) and synonymy (several terms express one and the same concept), and terms from other professions (commerce, technology, land surveying, social work, etc.) all hinder the easy understanding of legal texts (Mattila 2012: 30-33).

The list of characteristics of legal language in general or those of particular languages could be continued, but this is not the aim of this paper. Partly based on studies on plain legal language, on the one hand, and taking into account some conclusions of the mainly American movement of "law and language" (including courtroom studies and forensic linguistics), on the other, two Hungarian empirical research projects are going to be presented in the following chapters. Starting in 2000, these studies were carried out at the Department of Jurisprudence and Sociology of Law, University of Miskolc, and some of their conclusions focus on the comprehensibility of written and oral legal language.

\section{The first "law and language" research in Hungary (2000-2003)}

As the first empirical research in this field in Hungary, the project called Language Use in Legal Procedures: Language Translation and the Nature of Fact in the Process of Establishing Legal Statements of Facts was conducted between 2000 and 2003 in Miskolc with the cooperation of lawyers and linguists of the University of Miskolc. In the research, we sought to reveal and analyse the establishment of facts and the process of adjudication during the criminal procedure of gathering evidence at the police and at the court, during which lay narratives are translated into facts phrased in the legal register (this is what the Russian linguist Roman Jakobson calls "intralingual translation" between different codes or registers - in this case between lay code and legal code - within the same language; see Jakobson 1959). We identified the aim of the research as a dual task: the revelation of linguistic features of the lay and professional ways of speech on the one hand and the examination of the influence that the presence of power and coercion in discourse had on the process of the establishment of facts, on the other. We planned to analyse certain legal cases intensively rather than extensively. It was not our primary aim to strive to involve bigger case numbers in the research, but we wanted to follow a case for the longest possible period of time over the course of its proceeding, and we wanted to process it in the greatest depth. As regards the expected results, we declared already in the application that directly applicable results cannot be expected as we undertook to carry out a 
basic research with no precedent in Hungary; therefore, the main objective could be "only" awareness raising in a new research area and inspiration for further enquiries. However, being an interdisciplinary research, these results can be (and some already are) involved in the curricula of law and applied linguistics education in the future.

Our objectives were mainly fulfilled with minor changes. We carried out a unique research in Hungary, and as a result we could say that the development of the "law and language" research finally began in our country, which had been in place in other countries for decades. In addition, a further outstanding outcome of the research is that more than 18 hours' recording was made as the result of data collection, of which 14 and a half hours was made at police interrogations and 4 hours at court trials. This database enabled both linguistic and legal researchers to go on examining the language used in a legal process or analyse it according to their viewpoints. The first example of the fulfilment of this objective is a volume of essays and studies published in 2010, in which the participants of the research summarized the development of legal and linguistic research in the English- and German-speaking countries and analysed the research findings from legal and linguistic aspects (Szabó 2010).

During the empirical research, tape recordings of police and court hearings were prepared with the involvement of law students. We used participant observation as a method developed in cultural anthropology: besides making tape recordings, we recorded all the observations in writing, which could not be perceived in the recording. To prepare tape recordings, permissions were needed. We managed to sign a detailed written agreement on cooperation with the police headquarters in Miskolc; however, we faced difficulties at the court: the leaders of the judiciary provided only an oral permission; therefore, most of the judges did not allow us to record the hearings. This influenced the composition of the resulting database that - as mentioned before - contains much more recordings of police than court hearings.

At the police, besides preparing tape recordings of interrogations and confrontations, we made in-depth interviews with the lay and professional persons taking part in the proceeding. As regards suspects and witnesses, on the one hand, we tried to reveal their ordinary living conditions, education and literacy, and by this means we could exactly define their social status in relation to the style of their language use (a relation revealed by the discipline of sociolinguistics; see Bernstein 1971.) On the other hand, we wanted to inquire into the impression they obtained during the hearing. We asked them for their opinion of the interrogation officer, whether they understood his/her questions and could talk about everything they considered important in relation to the case. We also asked the police officers taking part in the interrogation about interrogations in general, which they conduct as part of their work, as well as 
about the concrete case we recorded. We did not manage to similarly interview the participants in court trials.

The exact and detailed analysis of tape recordings required transcription. We investigated various possibilities of transcription applied in linguistics and developed the transcription signs which are the most suitable for the aims of the different (linguistic and legal) analyses. Originally, we also planned to use the method of document analysis, which would have meant the comparison of transcribed versions of recordings prepared at police and court hearings and the official written records. Unfortunately, we could not carry out this comparison as we could not get the records prepared at police interrogations and court hearings from the officials.

From the several conclusions of the research (see more details in Vinnai 2017), two aspects are highlighted here with regard to understanding legal language. By developing the linguistic model of adjudication, it is stressed that in legal proceedings the efficiency and success of verbal communication is also the condition of the efficiency of the establishment of facts. From a legal aspect, the proceedings cannot be correct (fair) if they are not so from a linguistic, communication aspect. If there are problems, inadequacy, and distortion in the interaction between the lay and the legal experts, they will have an impact on the process of the establishment of facts and ultimately on the final results of the process, namely the judgment too. This statement - before the beginning of the empirical research - has been established by the results of the American "courtroom studies"; moreover, the hypothesis has also been proved by the analysis of tape recordings of the research in respect of Hungarian legal practice.

During the analysis of tape recordings, it was revealed that delivering information on rights and obligations of laymen by police officers and judges during the procedure takes place as required by law; however, its original aim has not been fully achieved. The recordings clearly prove that although investigators and judges comply with the regulations of the Code on Criminal Procedure and further legal norms, the mode or way of their communication often makes the essence of the warning insignificant, ineffective, and laymen can hardly understand them. Naturally, it is very difficult to prove as the records include the text of providing information, and they are really announced at the beginning of the interrogation (it cannot be left out by chance because from the beginning the sample of the records includes the warnings, out of which the investigators have to choose the most suitable one with respect to the given interrogated person). So, this statement cannot be justified even from the transcriptions of tape recordings; it can only be proved by listening to them. Consequently, the practice meets the strict requirements of law, but the warnings do not fulfil the function that they have been originally created for. 


\section{The second empirical research (2014-2018)}

The title of the project (Linguistic Aspects of Fair Trial. The Impact of Legal Language on the Fulfilment of Access to Justice) includes in itself the two keywords in focus: fair trial and access to justice. The research group consisting of lawyers, linguists, and computational linguists ${ }^{3}$ had the hypothesis that - the previously detected - intralingual translation put laypersons in a subordinate position, which hinders their access to justice; or, in other words (as it was elaborated above): a legal procedure cannot be fair from a legal point of view if it is not fair from a linguistic aspect. Another aim of the research was to build a database from which characteristics of Hungarian written and spoken legal language can be listed that make it difficult to understand for lay people. In order to achieve this aim, new voice recordings were also prepared at court hearings in 2017 (unfortunately, this time we could not sign an agreement with the police), and it provided opportunity to compare the former and the present Hungarian practice on delivering information by professional participants to lay persons on their rights and obligations.

By the end of the project, in 2018, the research group managed to build up a database containing different types of legal texts. The Miskolc Legal Corpus consists of the following 7 sub-corpora:

1. codes of law (Criminal Code, Civil Code, Labour Code, Procedural Codes, etc.),

2. other acts of the Parliament and decrees/regulations,

3. judgments of courts,

4. reasoning of acts of the Parliament,

5. course books for law students,

6. Internet forums, and

7. recordings (and transcriptions) of police interrogations and court hearings. ${ }^{4}$

The overall content of the database is more than 2 million words, which is approx. 150 thousand sentences. In the volume containing the closing conference presentations of the project, linguist members of the research group analysed and compared the main features of the different sub-corpora (Szabó-Vinnai 2018). Due to size limit, only one conclusion is mentioned here. Presuming that each layer of legal language has different linguistic features, i.e. legal language is not homogenous, one of the questions was: which types of legal texts are more comprehensible than others? According to the linguistic analyses, the following scale was drawn as regards the comprehensibility of legal texts (Vincze 2018: 33).

3 The website of the research is available in English: https://sites.google.com/site/otkamiskolcen/.

4 The database is available for researchers in order to carry out further analyses in their field of interest (https://sites.google.com/site/otkamiskolc2015/adatbazis_epites). 


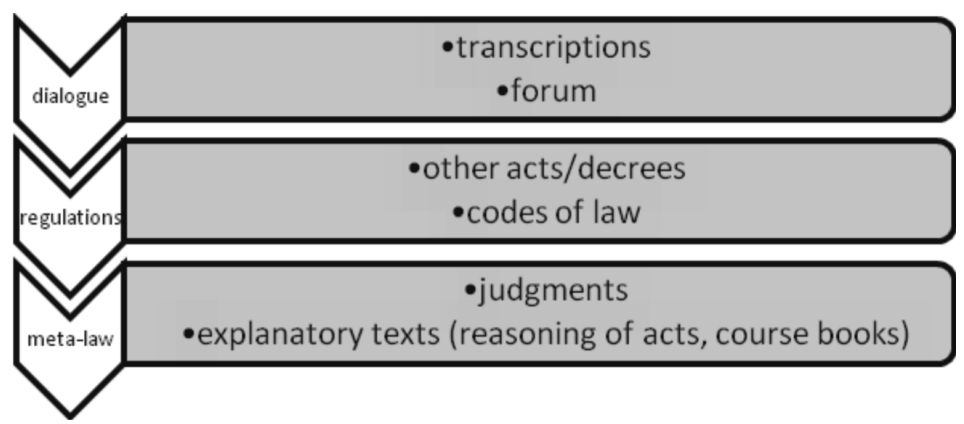

Figure 1. Scale of comprehensibility of legal texts

This scale shows that - taking different parameters of comprehensibility into account - spoken language in legal context (at police interrogations and court hearings) and the language of Internet forums are the closest to ordinary language, while - maybe surprisingly - the so-called meta-law (court judgments and explanatory texts and not the language of regulations) is the hardest to understand for lay persons.

\section{Some achievements as regards plain legal language}

In the last chapter, the most important achievements are collected with regard to applying plain language standards in Hungarian law in recent years. As the written form of legal norms is more important than their spoken version that is heavily based on codified texts, we need to consider this question on two levels: in the codification of legal norms and during their application.

(1) The activity of legislation, the codification process, i.e. the wording of written legal norms in clear language is crucial as regards the comprehensibility of legal texts because it influences all other fields of the operation of law. In 2010, the Clear Writing Campaign was launched in the European Union, and conferences were organized as part of it in several EU Member States, including Hungary, in 2014. At the conference, a representative of the Ministry of Justice declared that a lawyer-linguist internship programme was launched in the Ministry in order to improve the language of codification. However, even at the moment of preparing the manuscript of this paper, there is no official cooperation with linguists in the codification process in Hungary.

Training plain language experts working in the codification process would be very useful. Some universities offer postgraduate specialist training course in codification, where plain language standards can be taught, but undergraduate law students should also meet these standards during their studies; however, this rarely happens unfortunately. 
(2) In law enforcement, we can differentiate two further subfields:

(a) In the field of administration, we can see the first steps of applying the plain language perspective in practice thanks to a plain language organization. Two websites ${ }^{5}$ are operated by a plain language expert, where bad and good examples can be found of how to write legal texts clearly for laymen. Members of the organization also train employees of banks, insurance companies, and public utility services in order to make them capable of improving the comprehensibility of their written communication with clients. In some countries, researchers focus on how plain language saves time and money for governments and businesses (Kimble 2012).

(b) In the field of judiciary, we should further divide the area: as regards written decisions of courts, in 2014 and 2015, two working groups composed of practical and theoretical legal and other experts examined court judgments and collected their suggestions in a so-called Stylebook. The Stylebook lists several problems that need to be changed in court judgments in order to make them more accessible for laymen.

The other field within the judiciary system is oral communication at courtroom hearings. As it was mentioned, the first "law and language" empirical research in Hungary concluded that the way or mode of delivering information on rights and obligations by police officers and judges makes it ineffective because laymen can hardly understand it. However, new audio recordings collected in 2017 during the second research proved that the way of delivering information on rights and obligations improved a lot, partly because of legal regulations' amendments. By the time of the second research, some significant changes were enacted in connection with plain legal language and the better understanding of oral legal communication. In 2015, in accordance with the 2012/13/EU Directive on the right to information in criminal proceedings, the Hungarian criminal procedural act (Act XIX of 1998) was amended as follows:

62. $\S[\ldots]$ the court, the prosecutor and the investigating authority shall inform and advise the person involved in the action of his/her rights and obligations.

62/A. § (1) The court, the prosecutor, and the investigating authority shall strive to use simple and accessible language with the person involved in a criminal proceeding during oral and written communication. Information about rights and obligations has to be formulated in an accessible language, taking into account any particular needs of vulnerable persons.

(2) During oral communication, the court, the prosecutor, and the investigating authority shall assure that the person involved has understood the information on rights and obligations and, if necessary, explain them. ${ }^{6}$

5 https://vilagosbeszed.hu/, https://kozerthetofogalmazas.hu/

6 Translated by the author (E.V.). 
This amendment resulted that the Hungarian rules became in accordance with the Directive requiring Member States to provide suspects or accused persons with information on procedural rights (delivered orally for the non-detained) in "simple and accessible language". Furthermore, it "can be achieved by different means including non-legislative measures such as appropriate training for the competent authorities or by a Letter of Rights drafted in simple and non-technical language so as to be easily understood by a lay person without any knowledge of criminal procedural law" [Directive par. (38)].

In order to comply with the first part of these regulations, the Head of the National Office for the Judiciary (NOJ) announced that 2017 is the year of comprehensibility at courts. During the year, a compulsory training was organized for all judges where they were informed about the suggestions declared in the above-mentioned Stylebook in order to achieve simple and accessible language both in written and oral communication.

As regards the written Letter of Rights to be provided to detained persons, unfortunately, the Hungarian government and Parliament did not urge regulatory changes. In 2015, an NGO, the Hungarian Helsinki Committee, prepared an alternative Letter of Rights in the framework of a project titled Accessible Letters of Rights in Europe. The problem with accessible information on procedural rights was previously revealed in many European countries in a 2010 study called $A n$ EU-Wide Letter of Rights: Towards Best Practice, and the project was launched based on the findings of this study in some EU Member States, including Hungary. As a conclusion of the project, it was proved that the alternative Letter of Rights was far more accessible than the current one(s) provided for detained persons, and it was easier to understand for laymen because of the following reasons: legal terms were eliminated; references to acts were deleted; some examples and explanations were included; the whole text was less formal but more personal; and structural changes such as larger letter size, bold and italic letters, more fragmented text with bullet points, titles and subtitles, and table of contents were included (Moldova 2018).

\section{Conclusions}

Besides presenting some conclusions of two empirical studies carried out in Hungary and the unique Miskolc Legal Corpus database, the main focus of the paper is on the comprehensibility of Hungarian legal language both in written and oral communication in the light of access to justice and the right to fair trial. Some significant and positive changes can be detected in this field such as applying plain language standards in certain fields of administrative law, amendments of legal regulations, compulsory training for judges, and drafting 
an alternative Letter of Rights for the detained (although it is still not used in practice). However, as the written form of legal language is primary to spoken language, improvement of the quality of codified rules would be crucial in the future in the cooperation of lawyers and linguist experts.

\section{Acknowledgements}

The described article was carried out as part of the EFOP-3.6.1-16-2016-00011 "Younger and Renewing University - Innovative Knowledge City - institutional development of the University of Miskolc aiming at intelligent specialization" project implemented in the framework of the Széchenyi 2020 programme. The realization of this project is supported by the European Union, co-financed by the European Social Fund.

\section{References}

Adler, Mark. 2012. The Plain Language Movement. In: Tiersma, Peter M.-Solan, Lawrence, M. (eds), The Oxford handbook of language and law. Oxford: Oxford University Press. 67-83.

Bernstein, Basil. 1971. Class, codes and control: Volume 1 - Theoretical studies towards a sociology of language. London-New York: Routledge-Kegan Paul Ltd.

Bhatia, Vijay K. 2010. Legal writing: Specificity. Specification in legislative writing: Accessibility, transparency, power and control. In: Johnson, AlisonCoulthard, Malcolm (eds), The Routledge handbook of forensic linguistics. Routledge.

Gustafsson, Marita. 1975. Some syntactic properties of English law language. Publications of the Department of English 4. Turku: University of Turku.

Hiltunen, Risto. 2001. Some syntactic properties of English law language: Twentyfive years after Gustafsson (1975). In: Hiltunen, Risto-Battarbee, K.-Peikola, M.-Tanskanen, S.-K. (eds), English in Zigs and Zags. Anglicana Turkuensia 23: 53-66. Turku: University of Turku.

Jakobson, Roman. 1959. On linguistic aspects of translation. In: Fang, Achilles et al. (eds), On Translation. Cambridge, Mass.: Harvard University Press. 232239.

Kimble, Joseph. 2012. Writing for dollars, writing to please. The case for plain language in business, government, and law. Durham, North Carolina: Carolina Academic Press. 
Mattila, Heikki E. S. 2012. Legal Vocabulary, Tiersma, Peter M. \& Solan, Lawrence, M. (eds.) The Oxford Handbook of Language and Law. Oxford: Oxford University Press. 27-38.

Mellinkoff, David. 1963. The language of the law. Toronto: Little, Brown and Company.

Moldova, Zsófia. 2018. „Terhelt tájékoztatás” - A terhelti tájékoztató közérthetősége a büntetőeljárás kezdeti szakaszában [Comprehensibility of letter of rights at the beginning of criminal procedure]. Magyar Jogi Nyelv 2018/1: 30-35 (https://joginyelv.hu/terhelt-tajekoztatas-a-terhelti-tajekoztatokozerthetosege-a-buntetoeljaras-kezdeti-szakaszaban/).

Szabó, Miklós (ed.). 2010. Nyelvében a jog. Nyelvhasználat a jogi eljárásban [Law in its language. Language usage in legal proceedings]. Miskolc: Bíbor.

Szabó, Miklós-Vinnai, Edina (eds). 2018. A törvény szavai [The words of law]. Miskolc: Bíbor.

Tiersma, Peter M. 1999. Legal Language. Chicago-London: University of Chicago Press.

Vinnai, Edina. 2017. Jog és nyelv határán. A jogi nyelvhasználat nemzetközi és hazai kutatása [On the edge of law and language. International and Hungarian research on legal language usage]. Budapest: Gondolat. 